\title{
WAS SOVIET SOCIETY SOCIALIST?
}

Karen Kh. MOMDZHYAN, Dr. Sci. (Phil.), Professor, Head of Chair of Social Philosophy and Philosophy of History, Philosophy Department, Lomonosov Moscow State University, Moscow, Russia (karm48@mail.ru).

\begin{abstract}
The article is devoted to the typological characteristics of the Soviet society, which the author considers as a variant of the "Asian mode of production" that emerged in a European country on an industrial rather than agricultural basis. The author takes the view that the governmentalization of the means of production cannot be considered a step towards socialist construction, if it does not lead to the subsequent socialization of these means. A sign of social ownership is the absence of capable people in society who are forced to sell (give up) their labor power to the owners of the means of production, regardless of whether they are represented by individuals, groups of people, or even social institutions in which people perform pre-determined social roles. In the USSR, the author argues, non-parcellular private property emerged over the conditions, objects, and implements of labor, collectively owned by the party and state elite, who used the labor of people deprived of property and the ability to influence economic and social policy. The fact that the bureaucratic elite does not always seek personal enrichment, and some of the workers did not feel themselves the object of exploitation, does not change the typological characteristics of society. The author examines the objective reasons for the collapse of the USSR, which he considers the collapse of the polytarian and not socialist system, which has a historical perspective and can be implemented on a higher level of technology and technology development than now.
\end{abstract}

Keywords: capitalism • socialism • communism • Asian mode of production • politarism

DOI: $10.31857 /$ S013216250017622-7

This article is a translation of: Момджян К.X. Было ли советское общество социалистическим? // Sotsiologicheskie Issledovaniia. 2021. No 12: 37-45. DOI: 10.31857/ S013216250018018-2

The author is not one of the radical critics who consider the Soviet experience absolutely destructive. You should be a very prejudiced person to deny the merits of the builders of the USSR, which managed to prevent the collapse of Russia, create a relatively developed industry, advanced science, an advanced education system, and finally win the most terrible war, which mankind ever knew. Of course, the price paid for all these achievements was extremely high, but this is not a reason to deny the very fact of these advantages of the Soviet society. Nevertheless, I am convinced that the achievements of the USSR should be qualified as successes in state-building, which led to the creation of a powerful regime, which seriously claimed to get a world leadership. But the doctrinal tasks of Bolshevism, as we remember, were not limited to the creation of a strong army, a space industry or a brilliant ballet. They assumed something immeasurably more as the construction of a new society, which should base on justice and principles of freedom, equality and fraternity. We should state a question: has this goal been achieved, and if not, which were the reasons for this failure?

Was the October Revolution historically necessary? Justifying the need for revolutionary transformations in Russia, V.I. Lenin and other ideologists of Bolshevism proceeded from the Marxist doctrine of the historical doom of capitalism, the need to replace it with a socialist form of social structure. The classics of Marxism considered capitalism as an unfair form of social life, but justified its inevitable collapse not by moral considerations, but by the action of objective laws of history. 
They were convinced that the rapid development of the productive forces of capitalist society made inefficient and counterproductive production and economic relations based on private property and spontaneous market regulation of commodity production. Marxists believed that a way out of the series of economic, social, political and moral crises generated by this contradiction is possible only on the path of socialist reconstruction of society, involving the elimination of private property and bringing the processes of distribution and exchange in line with the planned social nature of production.

Historical development has proved, however, that the thesis about the exhausted potential of the capitalist system by the turn of the XIX-XX centuries has come to be incorrect. With all due respect to Karl Marx, a number of serious mistakes made by this great theorist should be recognized.

At the same time, the author, as a specialist in social philosophy, has no intentions to discard many concepts of the "materialistic understanding of history", considering them solid heuristic hypotheses. Rejecting the absolutization of these concepts, we can still respect them: the idea of the limited functions of project consciousness in the objective nature of people's activities; the idea of the subordination connection between its practical and spiritual forms; the idea of the functional priority of material production, which creates life-supporting products of "first necessity"; finally, the idea of the infrastructural role of the economy as a system of distributive processes and relations underlying the social infrastructure of society (stratification of society and shaping social groups) and influencing the political and moral orders of public life.

The author does not question the existence of economic classes, which play a different role in an organization of social production and have different attitudes to the conditions and means of labor. There is no doubt that classes have divergent economic and political interests in history, this gives their relations the character of conflict interaction, capable of turning into antagonistic opposition if we are talking about "sick" societies, which have exhausted their resources (however, history has known cases of "artificial antagonisms", which were the subjective result of unwise politics).

The mistakes made by Marx concern not so much the socio-philosophical or general sociological problems, as the problems of historical typology, which includes the question of the essence of capitalism and the historical prospects of its existence. Karl Marx mistook the birth pangs of "civilized capitalism" for the agony of this system. He clearly underestimated the historical possibilities of the bourgeois class, absolutizing short-term trends in the development of European capitalism associated with the "rentier economy", which is characterized by the massive refusal of the bourgeoisie from direct participation in the production process, the transfer of organizational functions to hired managers. It seemed to Marx that the entrepreneur class, which had once changed the face of Europe for the better, had already lost its creative power, its managerial role, having turned into a "parasite class", which "the necessity to be laboring has left."

On the other hand, Marx clearly overestimated the revolutionary potencies of the "working class". History has radically changed the appearance of this class, which is primarily due to the dispersion of production and economic relations, their going beyond material production (where they originally arose) and penetration into the spheres of organizational, social and spiritual activity, where the class-forming relationship "owner-employee" was previously absent or had a rudimentary character. People who sell their labor to the owners of the means of production have not disappeared from history. However, the nature of their work has changed qualitatively, which has broken the previously existing dependence between the lack of their own means of production and a need to sell their labor and poverty.

In a word, capitalism has not only been saved in the modern history, but also revealed almost a century of rapid development, which gave rise to the illusion of its eternity, identical to the "end of history". We realize the erroneous nature of these hopes only now, when humanity has once again entered the era of non-guaranteed outcomes of social processes, the bifurcation phase associated with the change of established models of social functioning.

The mainstream of historiography of the twentieth century convinces that the October Revolution in Russia was not predetermined by the objective logic of historical development, this revolution was in many ways a result of a large-scale fluctuation, which significantly influenced its course. 
Although history does not tolerate subjunctive moods, it is difficult to doubt that theoretically Russia could exist and develop within the framework of the capitalist paradigm, to which it returned at the end of the XX century. This does not mean, of course, that there were no objective reasons for the "October revolution", which was entirely generated by the "evil will" of the Bolsheviks and this is explained by their love of power or selfish motives. The leaders of Bolshevism quite sincerely considered themselves "agents of world history", realizing the objective goal of the communist transformation of mankind.

However, the subsequent course of events showed the fallacy of these hopes. And it's not just that "decaying capitalism" has survived. The fact is that the society created by the Bolsheviks was hardly socialist, qualitatively different from the previous "antagonistic formations". In order to argue this judgment, we must understand exactly what type of social structure can be considered as socialist one.

What should be called socialism? There are two interpretations of socialism as a form of social structure. In one case, experts talk about socialism, referring to the social system, which developed mainly in the countries of the Northern Europe ("Scandinavian socialism"). We are talking about a society, which experiencing still the market economy, this is systemically important for capitalism, basing on private property and focusing on the production of goods. At the same time, these foundations of capitalism are combined with the state policy of social partnership, which is based on the redistribution of benefits and powers, designed to dampen socio-economic contradictions, avoid destructive distortions in the lifestyle of entrepreneurs and workers, young and old, men and women, etc. It is clear that such an understanding of socialism did not correspond to the realities of the USSR and was not accepted by its creators, which refused to consider the "Scandinavian model" socialist, naming this a social-democratic version of capitalism.

According to the "Marxist-Leninist" interpretation of socialism adopted in the USSR, this social system is based not on the redistribution of public goods, but on a special method of their production based on public ownership of the means of this production. In a socialist society, as F. Engels wrote a century and a half ago, "the mighty productive forces ... should work only for the common welfare of all as their common property" [Engels, 1961: 199].

Creating a model of the future socialist society, K. Marx and F. Engels proceeded from the fact that the social ownership of the means of production characteristic for this existed already at the early stages of human history, forming the primary social formation as "primitive communism". The consequence of public ownership was a distribution system based initially on "collapsible relations", when each member of the collective (tribe), on the basis of his belonging to it, had the right to a share of the public product.

We should say, that there is in the modern social science the question of the existence of primitive communism the subject of controversy till now. Some authoritative scholars do not ignore a possibility that "the hierarchy and dominance so characteristic for prehuman herds was never interrupted and that there was no intermediate period of primitive communalism" [Gellner, 1992:50]. Other researchers doubt the fact of public property in early primitive societies. So, the famous British ethnographer I. Shapera insisted that the food and water necessary for life were private property of the Bushmen, belonging to the person who obtained them. A. Radcliffe-Brown also insisted on the existence of private property, the object of which was, first of all, food.

Without interfering with the professional problems of ethnography, the author would like to recall the difference between ownership of means of production and ownership of items of individual non-productive consumption. This distinction is of fundamental importance for social theory. Only the first form of ownership, represented by production and economic relations, acts as an initial factor of class formation, which is important for the typological characteristics of society. The ownership of consumer goods creates only property relations between people, dividing them not into classes, but into economic strata of relatively "rich" and relatively "poor". This division can not be the basis of the scientific typology of societies, since it is present everywhere (with the possible exception of early primitive societies). 
Considering the above, I would like to remind you of the once accepted distinction between institutions of "private" and "personal" property. Some experts consider this distinction to be a "fabrication" of the Soviet political economy, but the author does not think so. The object of private property, which has typological significance for social science, can be real and symbolic objects (in slave-owning societies, also people) used in the process of social production as a component of productive forces. Therefore, it is hardly necessary to call "private" ownership of items of individual non-productive consumption, which makes it possible to dispose of food, water or clothing. With this understanding the category of "private property" loses its economic and sociological meaning, denoting an eternal and unchangeable condition of any and all social life, excluding the possibility of its scientific typology.

I will add to what has been said that even ethnographers which call the ownership of food or water "private" admit that in the uncivilized societies they study, "everyone who has food is expected to give to those who do not have it." "The result of this custom," writes I. Shapera, "is that practically all the food produced is equally distributed throughout the camp," therefore, the social life of primitive tribes "approaches a kind of communism" (cit. by: [Semenov, 1992: 32]).

Let us return, however, to the phenomenon of socialism in its post-primitive understanding. No one will argue with the fact that the thinkers who reasoned about this type of social structure considered its economic basis to be public ownership of means of production, which in no case should be confused with state ownership. It is impossible not to understand that the socialization of means of production is qualitatively different from their nationalization, which became an economic basis of Soviet society. The classics of Marxism have repeatedly and persistently emphasized that the nationalization of means of production does not in itself create socialist relations between people. Such nationalization can only be the first necessary step towards genuine socialization. As F. Engels wrote, "the first act in which the state really goes as a representative of the whole society is taking possession of means of production on behalf of society this is at the same time its last independent act as a state" [Engels, 1961: 225]. At the same time, Engels noted, "recently, since Bismarck rushed to the path of nationalization, a special kind of fake socialism has appeared, ... declaring all nationalization socialist... If a state tobacco monopoly is socialism, then Napoleon and Metternich should undoubtedly be listed among the founders of socialism. When the Belgian state, for the most mundane political and financial reasons, undertook the construction of the main railways itself; when Bismarck, without the slightest economic necessity, turned the main Prussian railway lines into state property... all this was by no means a step towards socialism, neither direct nor indirect, nor conscious" [Engels, 1961: 222].

A nationalization of means of production becomes a step to a creation of a socialist system only if this nationalization leads to socialization and to a transformation of state property into public property. Without such a transformation a state property cannot be considered an alternative to private property. The same F. Engels wrote about this problem, who argued that a bourgeois state "whatever its form, is by its very essence a capitalist machine, a state of capitalists, an ideal aggregate capitalist. The more productive forces it takes into its ownership, the more complete will be its transformation into a total capitalist...the workers will remain wage workers, proletarians. Capitalist relations are not destroyed, but, on the contrary, brought to the extreme, to the highest point" [Engels, 1961: 222-223]. These words of Engels are the key to understanding the fundamental difference between public property and any and all forms of private property.

The author believes that public property as a social institution arises only if the people, which are forming society, are in the same relation to key means of production, that is, there are no economic classes in society, which participate in the production process without owning and disposing of its means. On the contrary, private property as a public institution is present as long as people (social groups) are forced to sell (or give) their labor to the owners of means of production, even if these owners are represented not by individuals, but by social groups and even social institutions in which people perform predetermined social roles.

In fact, hardly anyone will argue with the fact that the property of joint-stock companies consisting of hundreds and thousands of co-owners is private property in its non-cellular group form, 
since it uses the labor of people, which do not possess a property. Similarly, the state acts as an integrative private owner if the enterprises belonging to it continue to use the hired labor of people who are forced to sell their labor (even if such use takes into account its market value, avoiding unpaid appropriation).

In connection with the above, a question of fundamental importance arises: can it be argued that as a result of the nationalization of the means of production that took place in the USSR, Soviet workers, peasants and the "labor intelligentsia" became genuine, and not nominal, owners of means of production, real owners capable of disposing of objects, tools and products of labor in their economic interests, different from the interests of the party and state bureaucracy?

A sober answer to this question will lead us to understand that state ownership of means of production, which arose in the Soviet Union, was only called public, not being such in reality. At the same time, it is also obvious that state property in the USSR was qualitatively different from the bourgeois type of property. It was the Soviet Union where an economy was created that, taking in regard its most important parameters, as this was not capitalist, market-oriented and profit-maximizing, which, however, does not make it a socialist economy.

On the typological characteristics of Soviet society. Describing the Soviet system, the American historian-sociologist Karl-August Wittfogel, who sharply criticized it, argued: "Attempts to evaluate the phenomenon of communist totalitarianism as collective leadership and autocracy, the economy of power and the economy of consumption, self-reproducing and self-liquidating, will do more harm than good if we rely mainly on the experience of polycentric societies and neglect the only important precedent capable of successful long-term existence of total power: the despotism of the East" [Wittfogel] ${ }^{1}$

Accepting this point of view, the author agrees with the opinion that there were in the USSR - a European, not an Asian country, on an industrial, not agricultural basis, many features of the social system, which were recreated, which Karl Marx called the "Asian mode of production", and modern researchers call "politarism" [Semenov, 2008], "state mode of production" [Vasiliev, 2011], etc. The genesis of such an organization Marx associated with natural conditions that determined the special economic role of the state, without which the technical conditions of social production ${ }^{2}$ could not be formed, which led to the absence of the usual for Europe forms of private ownership of land.

The concept of the "Asian mode of production", as is known, provoked a number of largescale discussions that began in the USSR in the 1920s and 1930s and continued in the 1960s and 1970s. Some social scientists categorically denied and denies the real existence of this form of social structure, considering it as a complex synthesis of elements of slavery and feudalism.

Opposing the idea of the "Asian mode of production", many of its opponents are convinced that this theory contradicts the "unshakable" principle of Marxism, according to which the differentiation of property and the classogenesis associated with it necessarily precede the separation of powers, the processes of politogenesis and generate them. Hence, it is concluded that the state cannot act as an autocratic economic force that owns and disposes of means of production without appropriate sanction from the ruling class. It is believed that the state, not being a substantial economic force capable of self-support and self-development, cannot be considered not only as a pre-class institution, but also as an independent class, as many supporters of the idea of the "Asian mode of production" insist (in particular, K. Wittfogel, who argued about "a model of classes in a

\footnotetext{
${ }^{1}$ References to the famous "Oriental despotism" (1957) by K.-A. Wittfogel are given by electronic "samizdat" translation on Russian.

${ }^{2}$ It was primarily about the creation of large-scale irrigation systems necessary in the climatic and geographical conditions of Asia. "The elementary necessity of economical and shared use of water," K. Marx wrote, "imperiously demanded the intervention of the centralizing power of the government. Hence the economic function that all Asian governments were forced to perform, namely the function of organizing public works" [Marx, 1957: 132]. K. Wittfogel insisted on the special role of irrigation in Asian societies, who called these societies "irrigation empires" and talked about "hydraulic despotism". In the Soviet Union, the role of the "irrigation factor" was played by the largescale activities of the state to industrialize the country and rebuild the foundations of public life.
} 
society whose leaders are the owners of despotic state power and are not private owners and entrepreneurs" [Wittfogel]).

The stated point of view absolutizes one of the ways of political genesis, in which a state really arises as a product of class contradictions and acts as an agent of class influence. But history also demonstrates a different model of political genesis, in which the emergence of a state is associated with the need for power regulation of "common affairs" as solving life-supporting organizational problems of exogenous (defense and conquest) and endogenous for the group properties. The performance of this function creates role and status differences between people that precede class division and in some cases give rise to it.

Proponents of the "Asian mode of production" also keep debates within an own circle, understanding a nature of "Asian mode of production" in different ways. Some of them insist on the absence of private property and economic classes in political societies in their Marxist understanding. The author shares another point of view, according to which state ownership of the decisive means of production is a kind of non-parceled private property, which stays in the collective possession of the bureaucratic apparatus. The latter one forms an independent class that completely dominates society, using methods of non-economic coercion to work, which is exploitation, even when the exploited, as it was in the ecstatic period of the Soviet history, do not realize themselves as such, sacrificing themselves to state interests. A characteristic feature of politarism is that in this society power is not a function of property, but, on the contrary, the economic status of people depends on their place in the system of power. The absence of partial private property in this society does not prevent, but contributes to the worst form of exploitation - the exploitation of a person by the state, which excludes social equality of people, hinders the development of their individual freedom, without which the socialist structure of society is impossible.

Of course, this does not mean that the author does not see qualitative socio-political and cultural differences between the polytarian society in the USSR and "Asian despotism". It is obvious that the ruling strata in many of these despotisms (with some exceptions for Confucian China) were guided mainly by self-serving interests, exploiting the masses for personal prosperity and aggrandizement. The party-state leadership of the USSR (excluding the late stage of the country's existence) could sincerely believe in the ideals of socialism, considering the creation of a powerful state capable of solving the problems of industrialization of the country and ensuring the welfare of its citizens as a condition for their implementation. However, for the tasks of social typology, it is not the faith of people that is important, no matter how sincere it may be, but the real results of their activities, which in the case we are interested in were far from the original intentions.

About the reasons for the failure of the Soviet experiment. The failure of "socialist construction" in the USSR is caused by many circumstances. Some social scientists consider the main one to be the theoretical inconsistency of Marx's social theory, naming it as a variant of an unrealizable eschatological utopia. The author does not consider this approach to be fair. In fact, Karl Marx and leaders of Russian Bolshevism had very different ideas about the very essence of socialism and the conditions of its emergence. These differences are explicated in the position of K. Kautsky, a representative of "classical" Marxism, who did not accept the October Revolution and was declared a renegade in the Soviet Russia. Be that as it may, Marx is not responsible for the social experiments of people who decided to build a "new society" in a war-torn country and were guided by a worldview in which, according to the figurative expression of one of the critics, " $20 \%$ of Marx opposed to $80 \%$ of Stenka Razin."

In fact, the Soviet society stagnated and ceased to exist in 1991 precisely in full accordance with Marx's idea of "bad" industrial relations, which do not create proper incentives to work, thereby hindering the development of the productive forces of society. It was this circumstance that limited the economic efficiency of the Soviet society, which, despite the already noted high mobilization capabilities (especially those that manifested themselves in the first decades of Soviet history), could not provide the proper level of production, which creates the necessary conditions for human life. The total ownership of a state on conditions and means of labor combined with the futile attempts of its equally total planning had become an insurmountable obstacle to the successful economic 
development of the country. Alas, the state that liquidated the parcel private property turned out to be a bad entrepreneur in the end, inferior to private entrepreneurs in terms of the amount of initiatives and the effectiveness of their implementation. It is not surprising that the citizens of the richest country in terms of resources, which had high-quality education and ability to work, were forced to crowd in queues for two varieties of wet sausage in their free time from "space launches" and experienced a shortage of housing and even toilet paper.

Economic inefficiency was, of course, not the only reason for the historical failure of the USSR. Genuine socialism could not be built by a state that was guided by the ideology of sociocentrism, which ignored the subjectivity of its citizens, completely subordinating their interests to the arbitrarily understood interests of the country. The party leadership viewed its citizens as the "cellular basis" of society, as "cogs" of the social mechanism, which were obliged to serve the state, sacrificing their personal interests. Effective in the conditions of the military crisis, this ideology could not ensure the long and stable development of society, many citizens of which were taught to live by the orders of their superiors and consider personal initiative a dangerous and punishable action.

Not being an adept of the socialist idea, the author is sure that its supporters are doing it a disservice, calling the collapse of the USSR "a temporary failure of the socialist experiment." The unsuccessful one was not the socialist, but the polytarian system, which pretended to be socialism and demonstrated its incapacity in the conditions of modern history as very different from the conditions of the ancient and medieval East, where polytarian states could exist for millennia. At the same time, the collapse of the USSR by no means negates the theoretical prospects of genuine socialism, associated with the real socialization of the means of production, and not with their nationalization, with the free development of people, and not with state coercion.

Perhaps the idea of so-understood socialism cannot yet be realized in modern conditions at the current level of development of productive forces, in which a market economy based on private property still retains its effectiveness. However, the sprouts of a possible socialist mode of production are already visible. One of the indicators of this perspective is the fact that, there is in the citadel of modern capitalism, as in the modern USA, a growing sector of the economy in which means of production are the collective property of the workers which use them. We are talking about enterprises that are collectively owned by labor collectives, which allows them to make joint decisions that really affect the production process, its economic conditions and social consequences.

It is the ability to make independent decisions, to realize one's economic subjectivity, including to participate independently in the distribution processes, determining the size of the received share of public wealth, that the author considers to be a direct consequence of the ownership of means of production (different from the indirect consequences associated with the process of redistribution of the produced commodities). This type of economy, incorporated into the system of bourgeois production, of course, faces many difficulties and has many limitations. But the very fact of its existence and expansion testifies to the futility of efforts to bring the nature of appropriation in line with the social nature of production.

\section{REFERENCES}

Engels F. (1961) The Development of Socialism from Utopia to Science. In: Marx K., Engels F. Works. Vol. 19. Moscow: Gospolitizdat: 185-230. (In Russ.)

Gellner E. (1992) Marxist Book of Genesis. Etnograficheskoe obozrenie [Ethnographic Review]. No. 2: 35-51. (In Russ.)

Marx K. (1957) The British dominion in India. In: Marx K., Engels F. Works. Vol. 9. Moscow: Gospolitizdat: 130-136. (In Russ.)

Semyonov Y.I. (1992) On Primitive Communism, Marxism and the Essence of Man. Etnograficheskoe obozrenie [Ethnographic Review]. No. 3: 31-46. (In Russ.)

Semyonov Y.I. (2008) Polytarian («Asian») mode of production: essence and place in the history of mankind and Russia. Moscow: Magic Key. (In Russ.)

Vasiliev L.S. (2011) Evolution of Society. Types of society and their transformation. Moscow: KDU. (In Russ.)

Wittfogel K.A. [1957] Oriental Despotism. A comparative study of total power. URL: http://samlib.ru/s/ strahow_a_a/wittfogel-oriental-despotism.shtml (accessed 21.10.2021). (In Russ). 